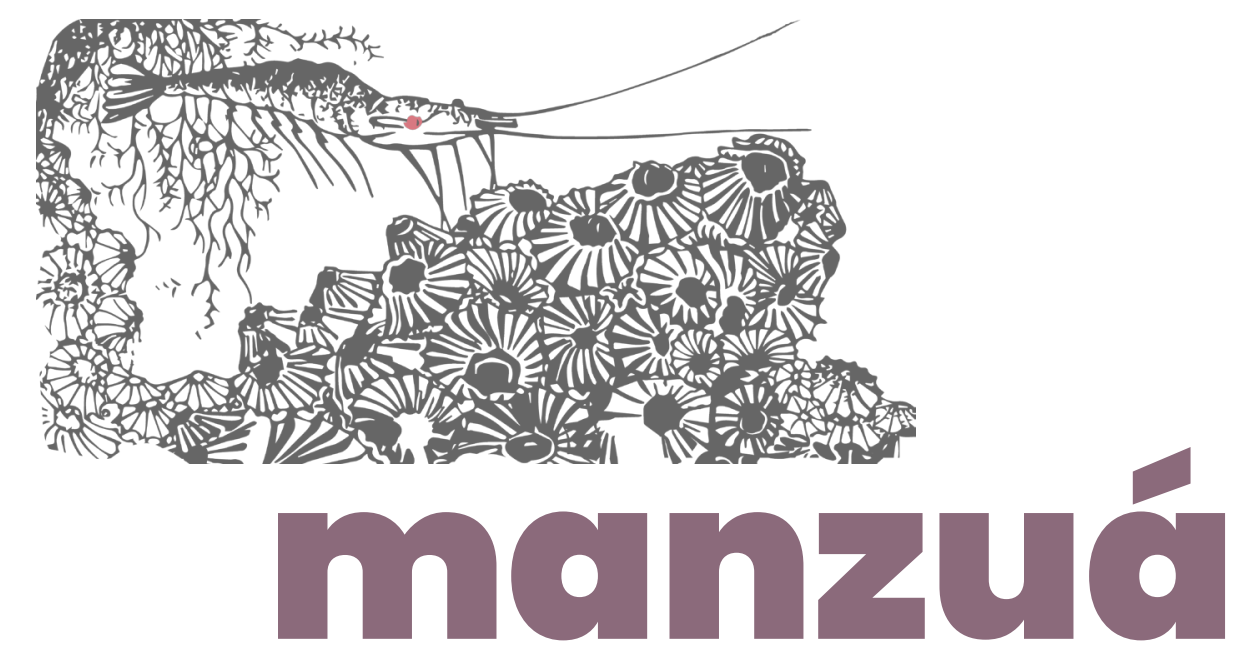

\title{
O LUGAR DE FALA NA FORMAÇÃO DO ESTUDANTE/INTEGRANTE DOS GRUPOS TEATRAIS ENQUANTO PROJETOS DE EXTENSÃO DO DEPARTAMENTO DE
} ARTES DA UFRN

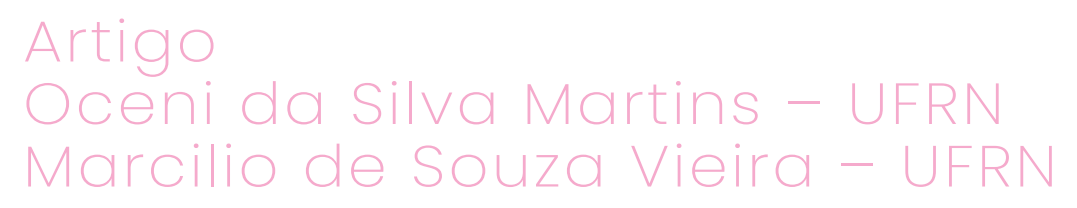

\section{Resumo:}

O texto objetiva refletir o lugar de fala na formação dos estudantes de grupos teatrais em projetos de extensão do Departamento de Artes da UFRN. A metodologia aqui desenvolvida se baseou na dinâmica de uma pesquisa qualitativa, num método descritivo, a partir das observações e a análise de conteúdo. Os projetos de extensão existentes na UFRN são oriundos de pesquisas desenvolvidas pelos professores, os quais divulgam uma espécie de ementa de seu projeto e assim ampliam a busca de participantes através do sistema Integrado de Gestão de Atividades Acadêmicas-SIGAA.

Palavras-chave: Projetos de Extensão; Grupos de teatro; Experiência

\begin{abstract}
:
The text aims to reflect the place of speech in the formation of students of theater groups in extension projects of the Department of Arts of UFRN. The methodology developed here was based on the dynamics of a qualitative research, a descriptive method, based on observations and content analysis. The existing extension projects in UFRN come from research developed by teachers, which disseminate a kind of menu of their project and thus expand the search for participants through the Integrated Academic Activities Management systemSIGAA.
\end{abstract}

Keywords: Extension Projects; Theater groups; Experience 


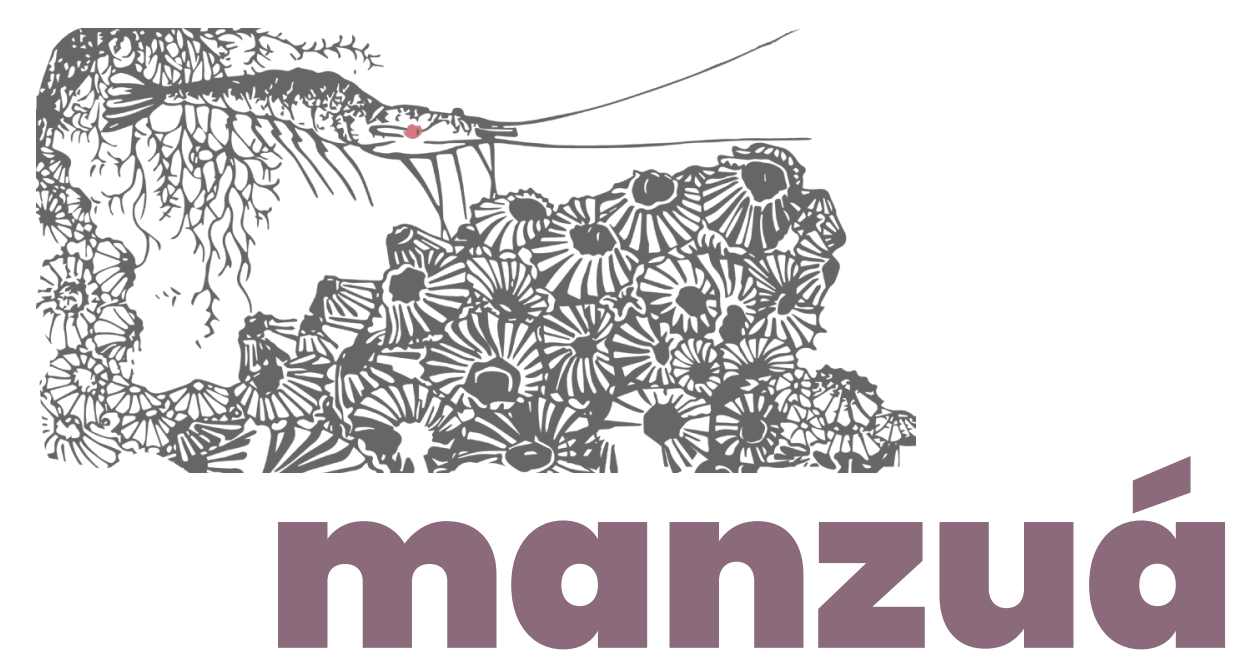

Pode-se dizer que a universidade é um dos locais propícios para a criação de grupos teatrais coletivos, em especial, nos cursos de Artes Cênicas. Tais grupos nascem da prática acadêmica de um grupo de pesquisa ou de extensão, constituído como um espaço de investigação teatral. Os espetáculos são geralmente resultantes de investigação cênica Artística/Acadêmica, que coletam elementos de diversas ordens, como os corporais, os imagéticos, os sonoros, os sociais, os históricos, dentre outros, para seus processos criativos.

Devido a sua inevitável especificidade, o teatro universitário ou o teatro na universidade, é um instrumento, como indica Germay (2010), insubstituível para a formação tanto no plano social quanto no pessoal de todos aqueles que exercem e dão força, sejam universitários ou não; logo, um teatro engajado, as vezes militante, mas com objetivos, normas, métodos e estilos próprios.

O texto objetiva refletir o lugar de fala na formação dos estudantes de grupos teatrais em projetos de extensão do Departamento de Artes da UFRN. A metodologia aqui desenvolvida se baseou na dinâmica de uma pesquisa qualitativa, num método descritivo, a partir das observações de Marconi \& Lakatos (2003) e a análise de conteúdo de Bardin (1977), visando obter a descrição do objeto estudado, de forma a permitir a inferência de conhecimentos relativos às condições de produção/recepção dos dados coletados (Bardin, 1977, p. 47).

Como técnica de pesquisa foi feito um questionário que foi respondido por integrantes ou ex-integrantes de grupos de teatro do Departamento de Artes, esses respondentes fazem ou fizeram parte desses grupos, a saber: GABOTUN, Grupo Arkhétypos, Grupo Cruor e Grupo Eureka. Os questionados assinaram um termo de consentimento livre para a publicação de suas repostas.

Os projetos de extensão existentes na UFRN são oriundos de pesquisas desenvolvidas pelos professores, os quais divulgam uma espécie de ementa de seu projeto e assim ampliam a busca de participantes através do sistema Integrado de Gestão de Atividades Acadêmicas-SIGAA. 


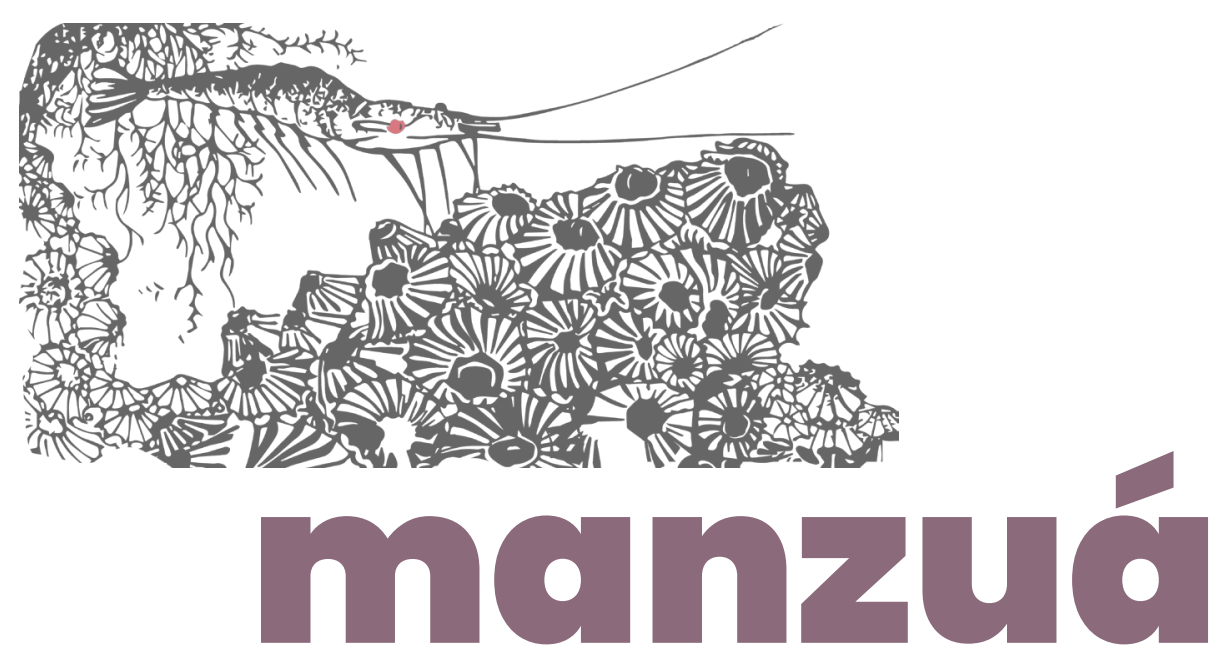

Esses participantes, em sua grande maioria, se identificam com a pesquisa divulgada pelo sistema universitário e se candidatam para a atuação no projeto. Em alguns casos, há ofertas de bolsas remuneradas, em outros, não, mas o projeto é mantido pela universidade como extensão universitária, em cuja resolução $\mathrm{N}^{\circ}$ 077/2017-CONSEPE, de 27 de junho de 2017, Capítulo I, Art. $2^{\circ}$, diz que ela é:

\begin{abstract}
o processo educativo, cultural e científico que articula o ensino e a pesquisa de forma indissociável para viabilizar relações transformadoras entre a Universidade $e$ a sociedade, a partir de um diálogo que envolva os diferentes saberes (das ciências, das tecnologias, das artes, das humanidades e da tradição), permitindo novas criações, socializações e mudanças recíprocas, com o envolvimento e inserção de alunos, professores e técnicos administrativos em experiências reais junto a diferentes grupos e populações que com elas interagem, por meio de ações que serão articuladas mediante as seguintes modalidades de extensão: I - programas; II - projetos (UFRN/CONSEPE, 2017, p. 1).
\end{abstract}

A extensão universitária possibilita aos alunos uma permanência nos grupos teatrais, auxiliando-os na sua formação. Com referência a essa formação, foram coletadas falas através de questionários com integrantes e ex-integrantes dos grupos citados, com o viés de ampliar esse olhar sobre a importância deles dentro da Universidade.

Foram feitas cinco perguntas aos integrantes do GABOTUN, Grupo Eureka, Grupo Cruor e do Grupo Arkhétypos. A primeira pergunta foi: "Qual a importância de participar de um grupo de teatro na universidade?"

Respondendo a essa questão Allan Phillype do Grupo Arkhétypos informou, que a maior importância que ele vê em participar de um grupo de teatro na Universidade, é a abertura de portas para ele no meio artístico. Hélio Júnior, da Cia GABOTUN, por sua vez, ressaltou que: 


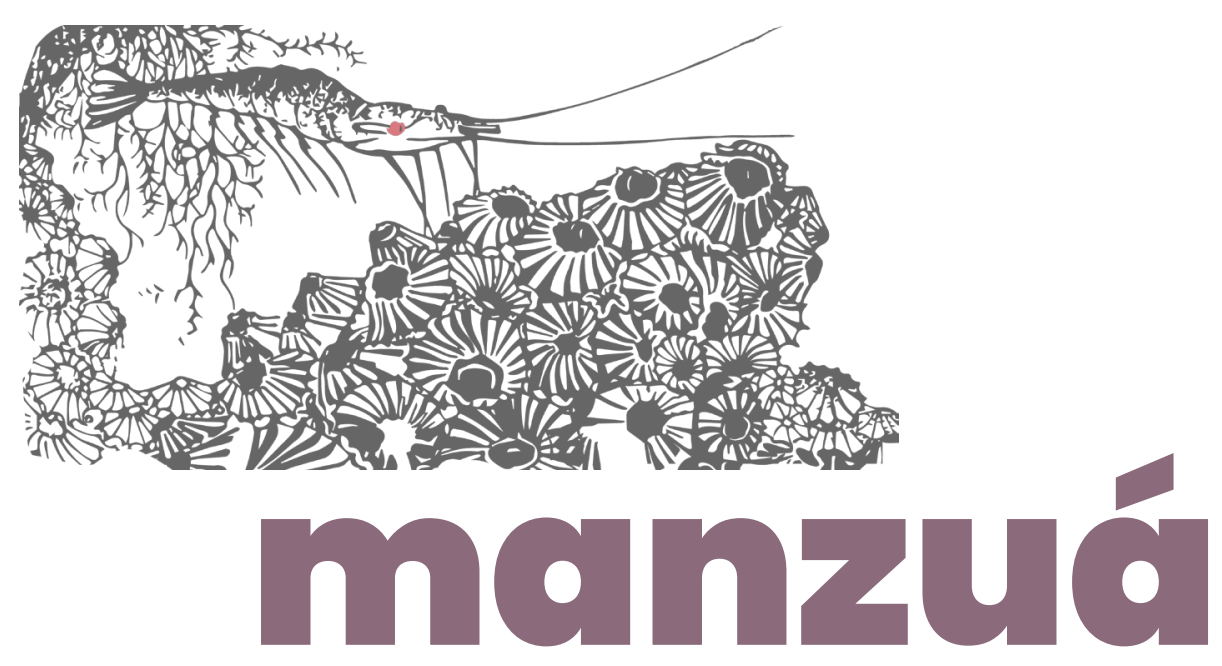

Antes de eu ingressar no Grupo GABOTUN (inicialmente era chamado de Grupo, posteriormente passou a ser Cia GABOTUN) eu já trabalhava com teatro, como: teatro de rua, e trabalhava como ator, diretor. Mas, o que destaco de interessante foi que o grupo me possibilitou estudar e conhecer mais Augusto Boal. Além do encontro com outros atores que se dedicavam a pesquisar o teatro do oprimido. $\mathrm{Na}$ época eu fazia o Curso de Letras e logo em seguida fui ingressar no Grupo de Teatro, isso me propiciou participar dos movimentos da Universidade através da linguagem artística, trazendo Augusto Boal para a universidade também, possibilitando ampliar a pesquisa teatral. (Hélio Junior, Cia GABOTUN)

Com a fala de Hélio Júnior, dá para perceber que além de uma participação ativa em um grupo de referência, ele tem a oportunidade de estudar e se aprofundar na pesquisa sobre Augusto Boal, na qual ocorre um aprofundar-se numa linguagem que conduz a reflexões politicas numa linguagem artística como o teatro fórum proposto pelo próprio Boal.

Referindo-se à sua participação em um Grupo de Teatro da UFRN, Anna Celina (Cia GABOTUN), assim se expressa:

Minha participação no grupo foi muito importante, eu estava chegando de Mossoró, não conhecia ninguém e nem conhecia a cidade direito. $\mathrm{O}$ grupo me proporcionou $\mathrm{o}$ contato com novos espaços na cidade e com outras pessoas de outros cursos que não o meu (ciências sociais). Além de ampliar o meu conhecimento acerca do fazer artístico. (Anna Celina, Cia GABOTUN).

Aqui Celina aponta como importante o conhecimento de Natal, e ainda, a melhoria da sua veia artística, o que contribui para o encontro com outros artistas, colegas de outros cursos e a construção de novos saberes. 


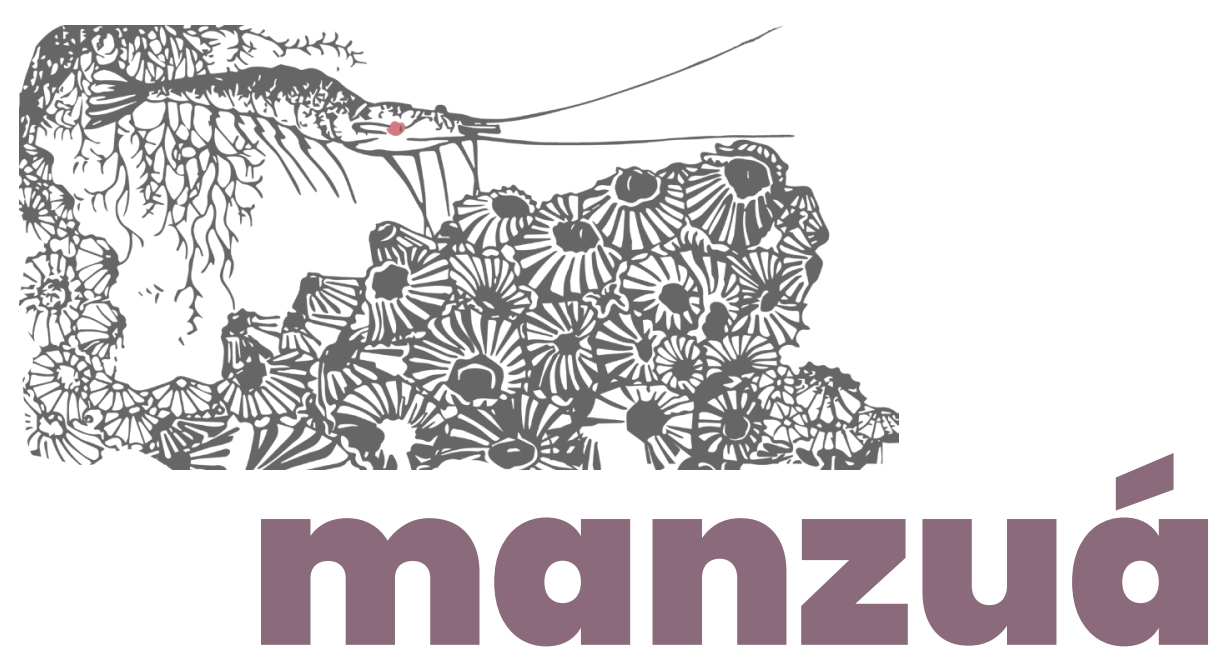

Por conseguinte, Natã Ferreira, do Grupo Cruor, relata:

Fui aluno de Artes Visuais na UFRN, participei de muitos projetos de extensão e devido o meu interesse em Performance Arte acabei entrando também em um grupo de teatro (Cruor Arte Contemporânea). Acredito que todas as atividades que fiz durante a minha graduação, fora a sala de aula, me proporcionaram muito mais conhecimento e vivências artísticas/humanas/afetivas do que em classe. A importância dos grupos de teatro e demais atividades extraclasse são justamente a troca que se tem com outras pessoas, que partilham de interesses comuns como a arte e a criação conjunta. Através disso a criação se torna prioridade e acabamos gerando uma rotina de trabalho. As coisas começam a perder o caráter de "trabalhinho de classe" e ganharem um aspecto mais "maduro" (Natã Ferreira, Grupo Cruor).

Observa-se no depoimento de Natã, a importância da troca de ideias com outras pessoas, o que leva a maturidade do grupo e dele como pessoa e profissional, reforçando que as atividades fora da sala de aula são impulsionadoras de um aprender fazendo teatro na prática.

Em seguida, Franco Wilamy do Grupo Arkhétypos, ressalta que:

O grupo do teatro, no meu caso me serviu de plataforma de pesquisa como ator e principalmente como arte pesquisador, pois nas experiências que tive além do acesso a montagem de processos criativos participei ativamente com pesquisa acadêmica, no primeiro grupo ao qual estou vinculado até o momento fui instrumentalizado também na organização de eventos e produção cultural dentro e fora da universidade. $O$ teatro de grupo foi onde pude exercitar e aprofundar noções que já eram de minha inquietação na formação curricular, além de claro poder dar acesso a mecanismos culturais dos quais eu não acessava antes. Dediquei-me fortemente as 


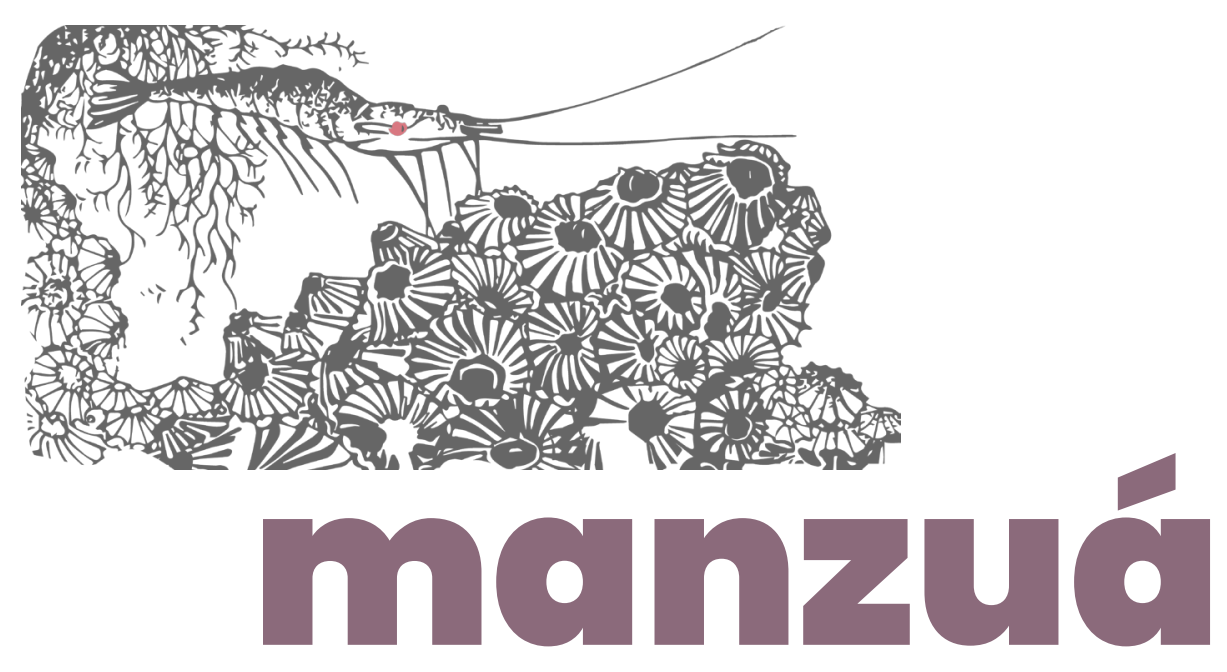

ações de dois grupos na Universidade o que me deu suporte formativo pra minha aplicação profissional hoje (Franco Wilamy, Grupo Arkhétypos).

Percebe-se na fala de Wilamy que ele não teve apenas acesso à pesquisa como ator, mas às montagens dos processos criativos, à organização de eventos e produção cultural, daí a importância de aprender a veicular a arte e não somente cria-la dentro da UFRN, mas fora dela, atingindo outros públicos.

Denilson David, na sua fala, reforça que:

Participar de um grupo de teatro na universidade é algo extremamente significativo para o complemento da sua formação, tanto como artista, quanto como educador. Uma vez que no espaço do grupo, você tem a oportunidade de colocar em prática tudo aquilo que se estuda na academia. É um momento de partilha e de crescimento mútuo. Como artista você pode experimentar todo o processo de concepção, construção e produção e realização de um espetáculo. Como educador, você pode desfrutar um pouco da pedagogia teatral, na troca daquilo que se sabe com o outro, seja em um momento de condução de algum jogo/ atividade ou no próprio dia a dia da rotina do grupo (Denilson David, Grupo Eureka).

Assim, podemos notar que ao participar de um grupo de teatro na Universidade, há a possibilidade de aglutinar experiências no fazer artístico, ou seja, experimentar a arte, criar, conceber, produzir espetáculos, o que vem a construir pedagogicamente o artistaprofessor.

No olhar de João Vitor, percebe-se uma menção à experiência do outro, que compartilha o conhecimento, reforçando que: 


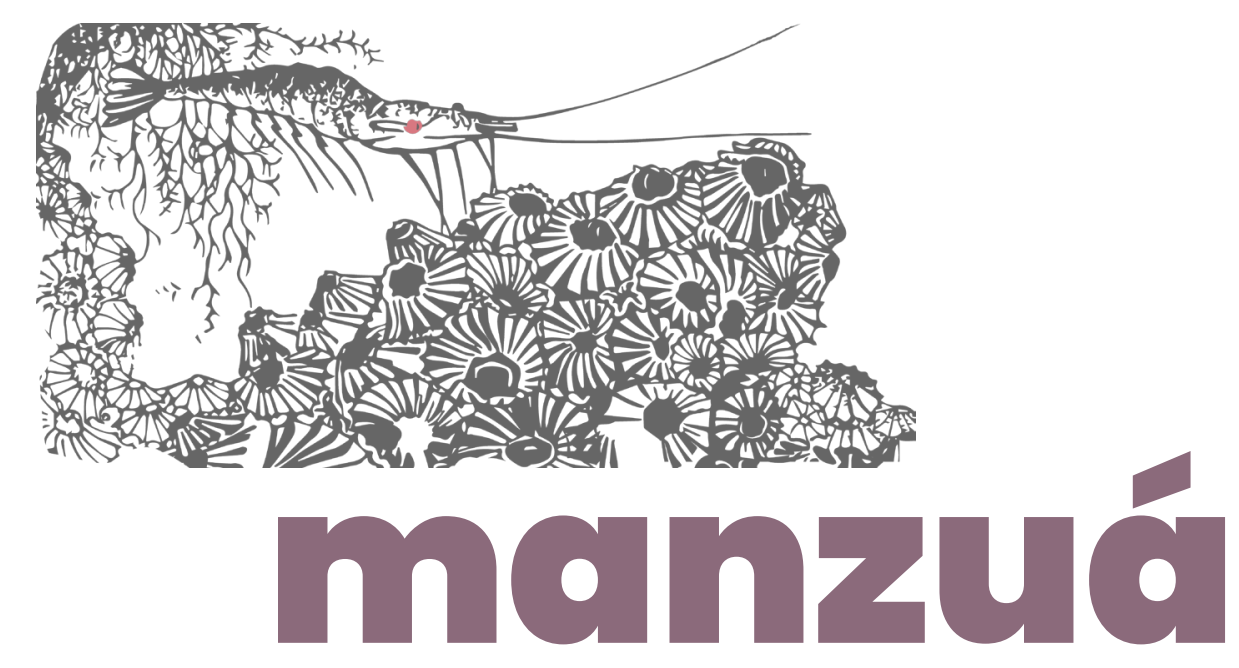

A importância é porque de certo modo a gente já pega a bagagem daqueles que já estavam em momentos anteriores, e isso a gente vê entrar em atividade as teorias e as práticas estudadas em sala de aula. Isso é fundamental. Quando saímos da sala de aula, da universidade, desse lugar, nos deparamos com a realidade que de certo modo, existe apenas nas nuances. Quando estamos participando de um grupo na universidade, a gente vê tudo que é discutido em sala de aula, como por exemplo, nas aulas de Nara Salles, que ela falava sobre performance. E o cruor é isso, é esse manifesto, essa pluralidade, é algo que não está fechado, ele é algo que aceita as diferenças, assim como a performance. E essa é a relevância, porque soma-se os conceitos que se começou a trabalhar e que as vezes não vemos em outros grupos externos a universidade. É como se no grupo da universidade a gente discutisse a teoria e prática por ela ser relevante (João Vítor, Grupo Cruor).

Logo, se entende que é relevante unir teoria e prática para ajudar na compreensão dos conceitos trabalhados em sala de aula, discutindo a pluralidade como matriz do conhecimento numa abordagem performática, onde o aluno pesquisador passa a atuar em outros espaços além da universidade.

O que se observa é que é dada uma importância muito grande em se pensar o teatro de grupo na extensão universitária e na formação de seus integrantes. O fazer artístico dessas pessoas em seus grupos de teatro, de certa maneira, contribuíram para ampliar seus repertórios de conhecimentos sobre diversas estéticas teatrais, difundindo a prática teatral na universidade e fora dela. As respostas dos entrevistados, também apontam a oportunidade que eles tiveram de crescer pessoal e profissionalmente, no âmbito da Universidade.

É interessante pensar e resgatar a importância do fazer teatral não somente estudando as suas estéticas, que são importantes, mas é fundamental considerar o fazer artístico (a prática propriamente 


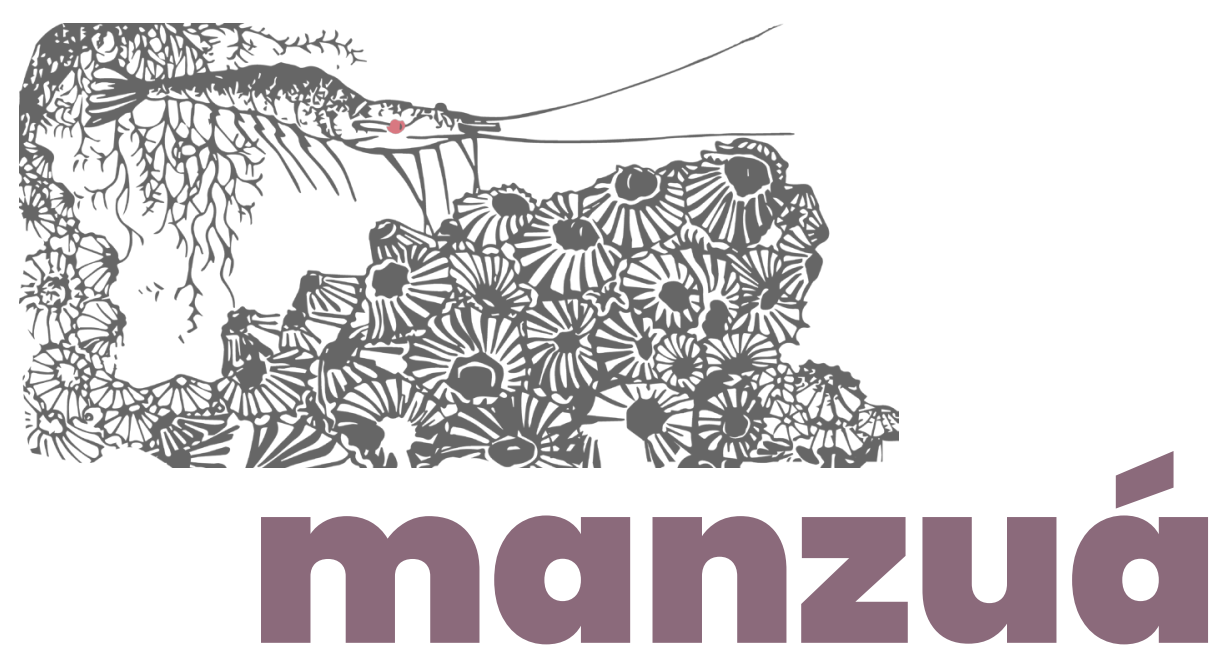

dita) como uma ferramenta de encontro consigo mesmo e com o outro, através de uma aprendizagem que leva a novas trocas de experiências, concretizadas num fazer artístico unindo a teoria à prática, possibilitando novos olhares ao teatro.

A prática artística teatral pode ser trabalhada em escolas e universidades para a formação do ser. Assim, o teatro passa a ser um elemento mediador entre a pessoa que atua (artista, ator) e a pessoa que vê (espectador), possibilitando "atravessamentos", que vão além de uma linguagem artística, que norteia uma determinada estética teatral, como é o caso do teatro do oprimido relatado anteriormente na Cia GABOTUN.

O atravessamento, conforme Sebastião de Sales Silva (2017), ultrapassa o campo da experiência. Se na experiência, somos tocados, transformados pelo vivido, no atravessamento, além de sermos transformados, nos deixamos afetar (Silva, 2017, p. 29). Ou seja, no teatro o ato de "atravessar" fortalece a comunicação com o outro, pois ocorre o entrosamento que se concretiza ao ser tocado pela arte alheia. Logo, quando ocorre a transformação, os atravessamentos se concretizam.

Dando continuidade à análise das questões respondidas pelos artistas de cada grupo, passamos a relatar, o que foi revelado a partir da pergunta: Como esse grupo contribuiu/contribui para sua formação?

Sobre a formação, Allan Phillype revela que:

O grupo que faço parte, o arkhétypos, abriu meus olhos para uma nova forma de se fazer teatro e de repensar meu corpo. Principalmente sobre as questões de respeitar as diferenças entre várias pessoas diferentes. Foi muito importante para a minha formação. (Allan Phillype, Grupo Arkhétypos).

Na fala de Allan, notamos que o Arkhétypos tem uma preocupação com a questão das diferenças e incute no grupo um olhar o outro sem 


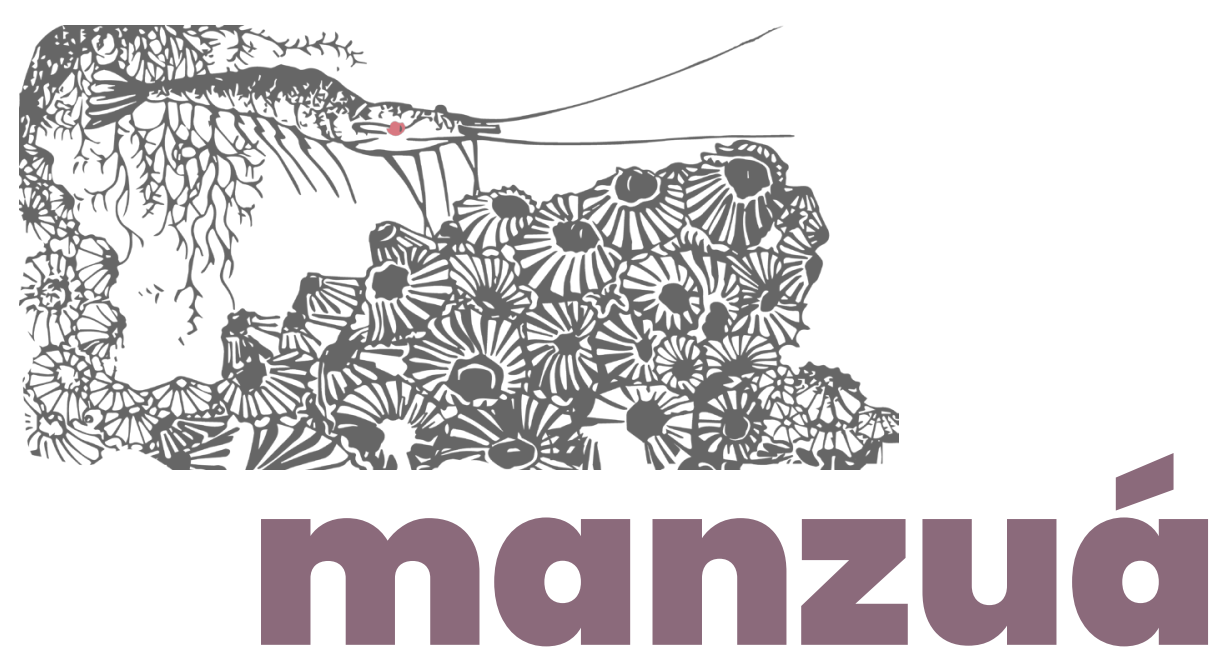

preconceito, é o respeito a diferença, onde se entende que cada um pensa e age de maneira única sem haver com isso a discriminação. Hélio Júnior, por sua vez, assim se expressa, respondendo à questão:

Eu já vinha fazendo teatro, e claro, era um momento de interagir, aprofundar mais o teatro político. Um teatro voltado para as discussões sociais. Um teatro de resistência. E isso foi importante pra minha formação. Embora eu viesse trabalhando com teatro oprimido, teatro comunitário desde 1980. Na universidade isso acontece de forma mais sistematizada, porque no teatro de rua você trabalha vários autores, vários diretores e o Boal estava ali também presente na prática. Reforçando, o grupo de teatro na universidade para mim foi de suma importância porque centramos mais no estudo do teatro do oprimido. (Hélio Junior, Cia GABOTUN).

Entende-se aqui que o GABOTUN tinha um trabalho sistematizado para ele, que vinha de um teatro de rua e isso abriu um novo olhar para as discussões sociais, unindo a teoria à prática através do teatro do oprimido.

No relato de Natã Ferreira, do Grupo Cruor, temos:

Esse grupo em especial me apresentou pessoas maravilhosas, cada um com suas questões pessoais, que juntos criamos um corpo político de resistência na nossa forma de criar (mesmo sem perceber muitas vezes), dentro de nossas possibilidades para aquele período curto de quase 2 anos de trabalho conjunto. Também o que mais aprendi foi como lidar com conflitos em grupo de arte, sendo a maioria dos integrantes do curso de teatro, os conflitos acabavam muito viscerais, o que agora, olhando para trás, chego ao riso. Também aprendemos a ser bastante "autônomos" em nossas formas de compor e criar, já que, na prática, não éramos coordenados por nenhum docente. $O$ 


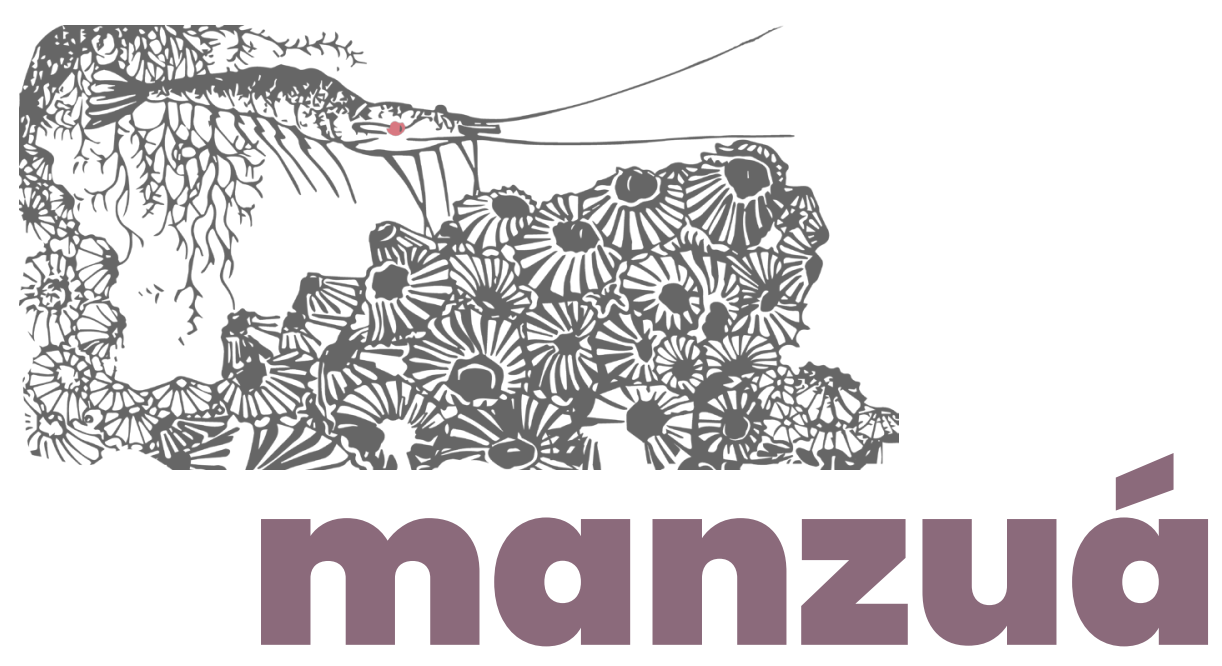

ponto negativo dessa autonomia era que nunca sabíamos muito bem as "finalidades" das ações, que já existiam antes da minha entrada no grupo, e os conceitos que éramos subjugados nos trabalhos desenvolvidos. Dessa forma cada um empregava seus palpites, trazendo seus conhecimentos pessoais e acadêmicos, se agarrava na bolsa (que era necessidade de vida financeira para todos, digo isso por importância política), e seguia produzindo. Então acabava sendo como um emprego mesmo (nesse caso específico desse grupo). Ou seja, o grupo com bolsa foi um sustento financeiro necessário para manter os meus estudos na graduação" (Natã Ferreira, Grupo Cruor).

Percebe-se que Natã, no seu depoimento, mostra ter unido o útil (bolsa remunerada) o agradável (compor, criar) teatralmente falando. Vê-se que existia uma questão de resistência e política no corpo do grupo, contudo, era preciso lidar com os conflitos para se manter na bolsa, que, para ele, era o meio de se manter no curso de graduação em teatro. Observa-se uma colocação muito forte com relação à necessidade de sustento financeiro por parte do depoente.

Denilson David, do Grupo Eureka, por sua vez, assim se expressa:

Me fez amadurecer, como pessoa, artista, como educador. Lá eu pude errar, cair, levantar. Me preparei para o mercado, para a sala de aula, para a vida. A rotina de um grupo de teatro, a convivência com o outro, todas as dificuldades e superações vivenciadas, proporcionam lições que você não encontra na academia (Denilson David, Grupo Eureka).

Nota-se que o grupo, para ele, foi o lugar de crescimento pessoal e profissional, podendo ser traduzido como um laboratório de criação e experiência para a vida, o que possibilitou a Denilson uma preparação ao mercado de trabalho e ao agir em sala de aula, como educador, pois conforme o seu relato, essa vivência mais profunda 


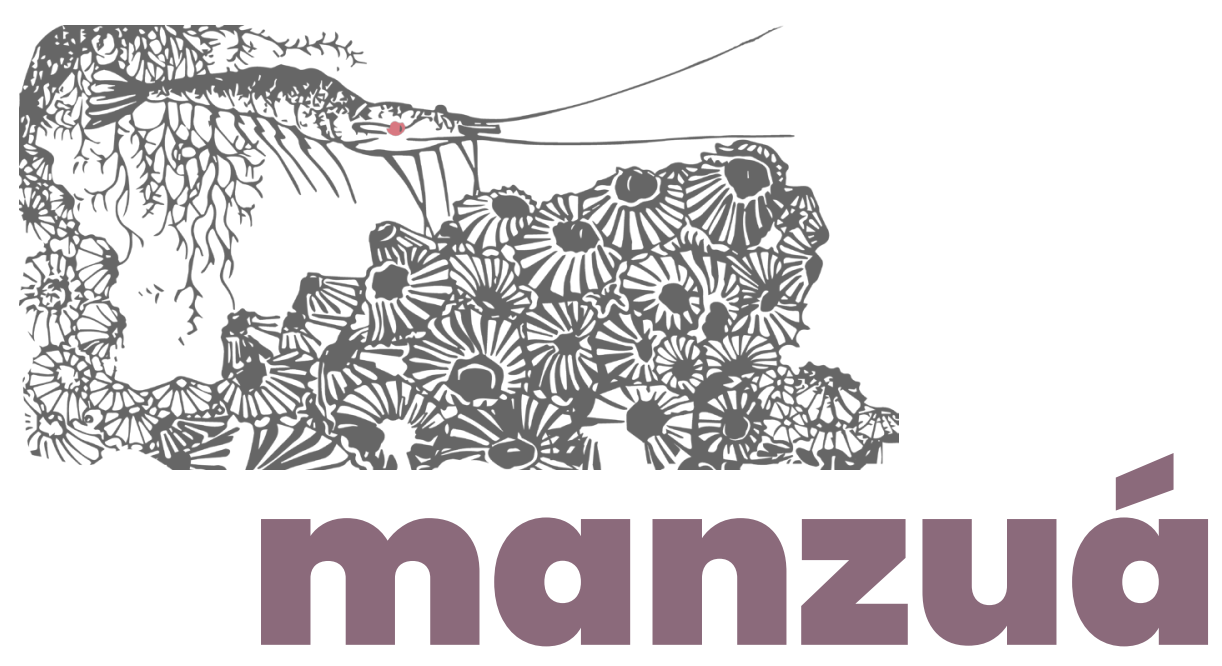

não ocorre no âmbito da academia.

Anna Celina, da Cia GABOTUN, no seu depoimento, declara:

O grupo me proporcionou leituras fora do meu universo acadêmico, conhecimento do corpo, da fala, da voz, da interpretação de texto, de encontros com novas perspectivas de visão da cidade e dos cidadãos (Anna Celina, Cia GABOTUN)

Observa-se que o grupo ampliou o repertório de conhecimento de Celina no sentido de um novo olhar sobre o corpo, lidar com a fala, a impostação da voz e, dentro do universo da leitura, a oportunidade de interpretação de textos além do espaço universitário, se apropriando de novos saberes também com relação à questão de que a cidade é um reflexo do cidadão, uma vez que cada um, na sua criação, poderia contribuir para a transformação da sociedade, inclusive, através das práticas teatrais.

E, esse olhar o corpo e enxergá-lo se repete no relato de João Vitor, do Grupo Cruor, quando diz:

O grupo contribuiu pra minha formação de modo significativo, por que eu comecei a enxergar no meu corpo, um corpo político, e não somente um corpo no espaço, aquele que se coloca a margem pra defender uma causa, pra falar sobre algo, pra discorrer sobre os fatos, e o cruor tem esse caráter. Ele quer evidenciar algo, quer apresentar e discutir. E a cada vez que eu entrava em cena no grupo cruor, que foi a partir da performance urbana "homens libertos", era pra quebrar os padrões estabelecidos na sociedade. Esse pensamento eu dou continuidade na minha pesquisa de mestrado. Um corpo político, que se coloca em cena pra atingir algo, por um motivo. Essa é a maior contribuição que o grupo me deixou, artisticamente e humanamente. (João Vítor, Grupo cruor). 


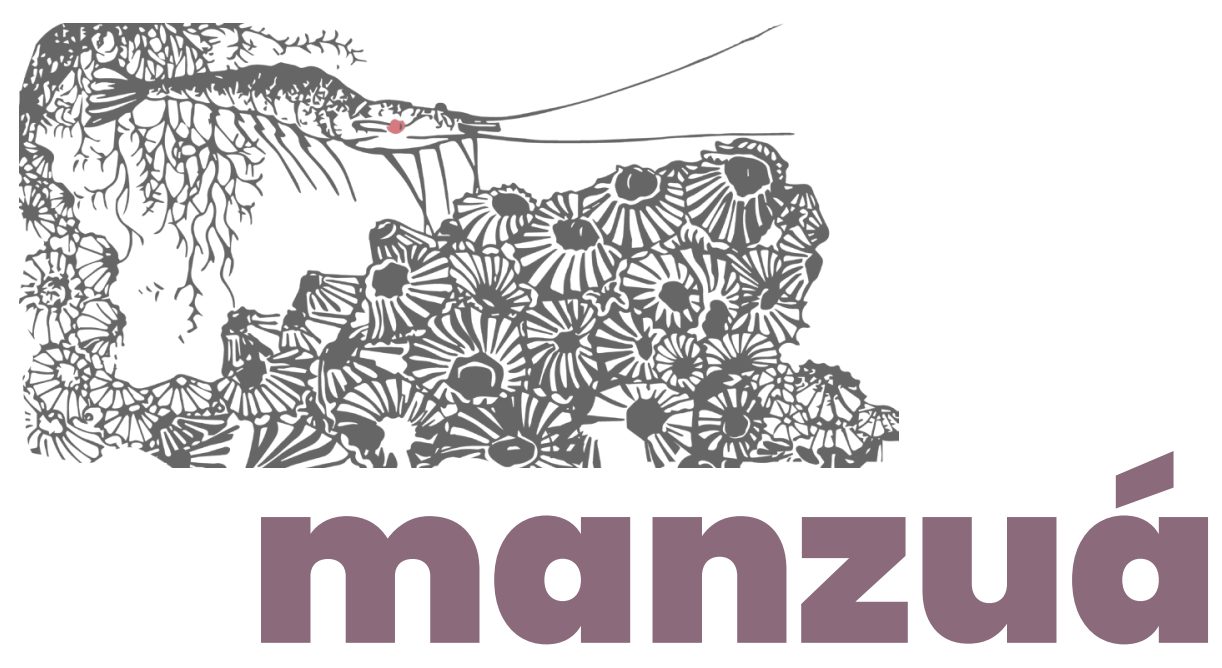

Constata-se que o grupo Cruor tem uma estética política, conforme João Vitor, quebrando padrões de corpos estabelecidos socialmente, no sentido de se soltar como artista, se deixando ver como homem livre no espaço cênico. $\mathrm{E}$, considerando a nossa análise, com relação à teoria e à prática acadêmica, Franco Wilamy, do Grupo Arkhétypos, reforça que:

Para além do que se registra curricularmente, nos certificados de apresentações inclusive internacionais, nas diversas oficinas e workshops, bem como na habilitação na organização e produção de eventos. O grupo contribuiu para me profissionalizar na prática, nos encontros cotidianos na gestão das atividades e no meu caso em especial, sou muito grato por ter apreendido e experimentado metodologias de criação e maturidade estética ao ter um espaço pra experimentar, trocar e aprender. Se hoje ministro oficinas de teatro e tenho uma trajetória mais voltada para pensar o corpo na cena e os exercícios de atuação isso se deu nas experiências do grupo, no exercício da autonomia e mediação que aprendi com meus encenadores e mestres. Minha iniciação científica também se deu no grupo de teatro, as noções que carrego hoje de arte pesquisador estão completamente fomentadas das experiências no grupo de teatro universitário (Franco Wilamy, Grupo Arkhétypos).

Das colocações de Wilamy, depreende-se que o lugar dos encontros, a prática, a gestão das atividades, a experiência no grupo, as metodologias experimentadas, trouxeram-Ihe maturidade, e hoje, reverbera na sua atuação profissional, daí o sentido de gratidão reforçada pelo artista-professor-pesquisador na sua prática àqueles que lhes orientaram no espaço acadêmico.

Dando continuidade as reflexões provenientes da nossa pesquisa, a próxima questão a ser analisada é: O que significa pertencer a um 


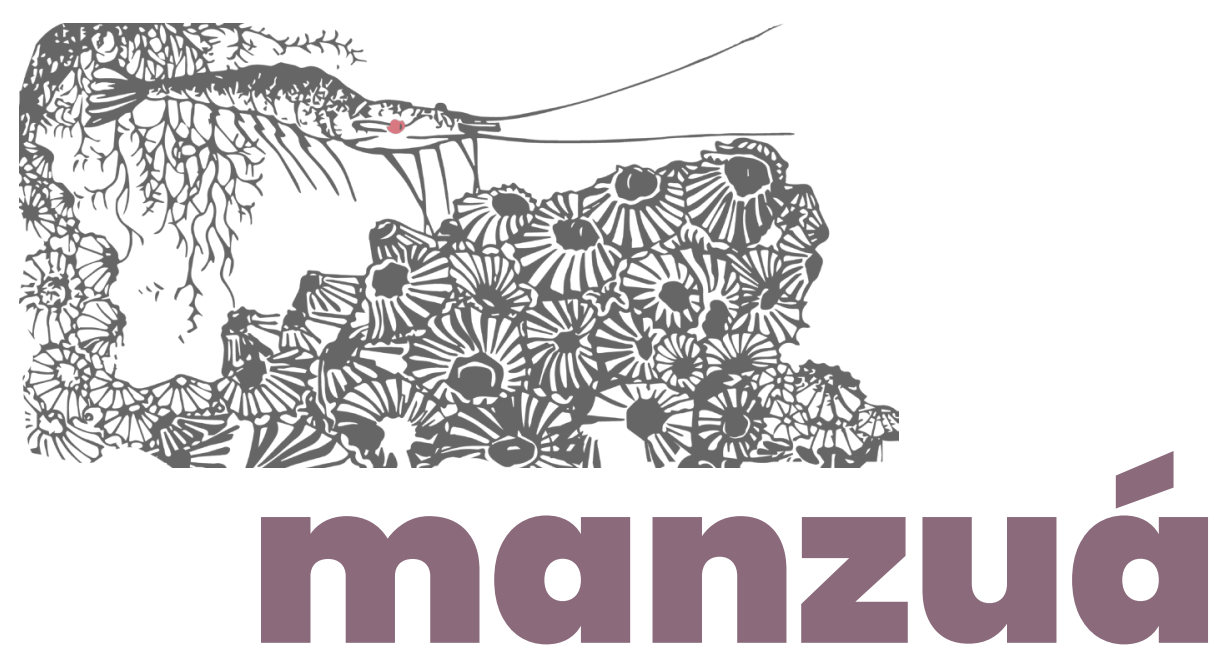

grupo de Teatro Universitário? A qual teve como respostas o que relatamos a seguir.

Para Allan Phillype, do Grupo Arkhétypos, pertencer a um grupo de teatro universitário "é uma oportunidade" e significa, para ele, ter esperança de que ele pode vencer na vida, fazendo teatro, além de se tratar de uma experiência de grande importância.

Já em Hélio Júnior, da Cia GABOTUN, temos que ele se coloca como um "nós", observado no relato abaixo:

Nós tentamos nos organizar em uma abordagem específica do teatro, sistematizamos o pensamento, fazemos experiências, pesquisas e isso é muito bom. Embora saibamos que o teatro na universidade é temporário, o grupo em si é temporário, ou seja, as pessoas que passam pelo grupo. $O$ grupo pode ficar 10, 20,30, 50 anos, mas o mesmo é rotativo, vai terminando o "curso", e os participantes vão para outro grupo de teatro, vão seguir a vida profissional, alguns saem da universidade. Percebe-se um fluxo grande que é por um lado positivo e por outro as abordagens vão se modificando, novas pessoas vão entrando e surgindo novas ideias, novos projetos, e isso aconteceu com GABOTUN de certa forma. Era um grupo base (GABOTUN) e depois teve pessoas que vieram participar do grupo, com novos projetos, com espetáculos novos, como: auto de natal, e outras montagens que foram projetos seguintes. Mas, um espetáculo que marcou o GABOTUN foi o "Fome causa x", com a perspectiva do teatro do oprimido. Montamos outro espetáculo (primeiro trabalho do grupo) chamado "privatização versus greve" que foi apresentado no período da greve dos professores, trabalhando diferentes tipos de professores (Hélio Junior, Cia GABOTUN).

Na verdade, Hélio Júnior não responde a pergunta posta, no entanto, ele nos apresenta as transformações que podem ocorrer ao longo dos anos nos grupos de teatro academicamente falando, uma 


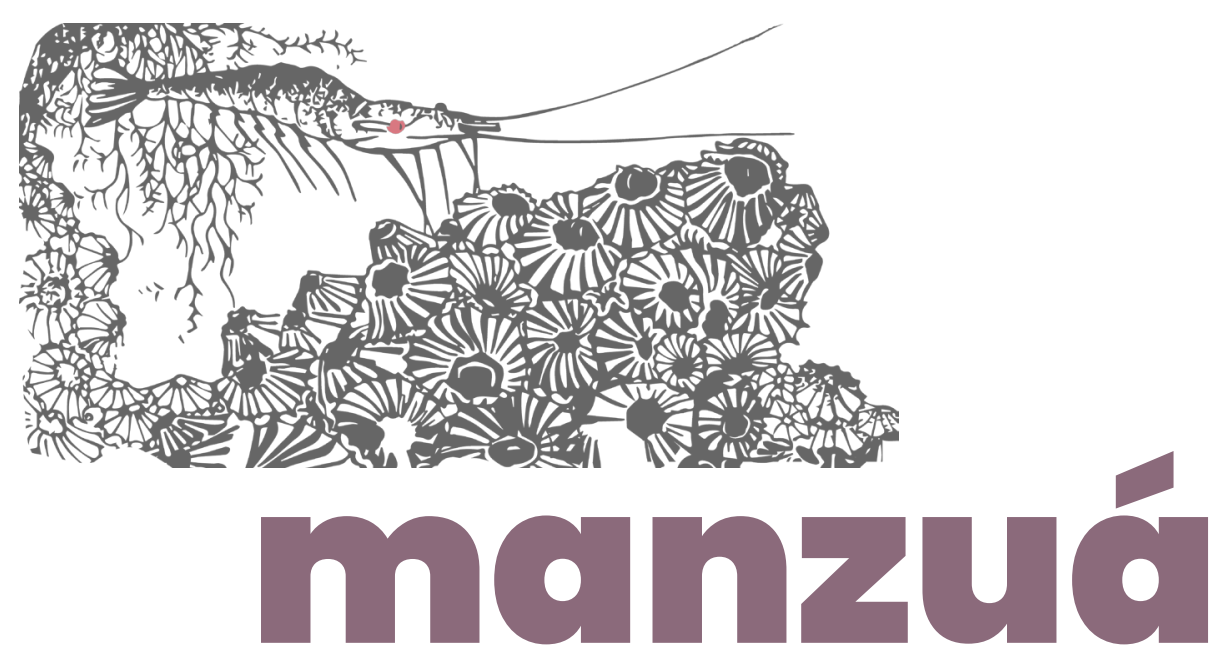

vez que estar na universidade é uma ação temporária e, à medida que as pessoas, estudantes, docentes vão passando, as montagens, os projetos e as abordagens se modificam também por novas ideias para a construção de espetáculos diferentes. A essência do GABOTUN ficou, porém, ele vai se transformando a cada nova formação de grupos teatrais.

Na contribuição de Anna Celina, da Cia GABOTUN, reforça-se que participar do grupo, para ela, foi um despertar para a formação teatral, mesmo que a mesma não tivesse seguido a profissão, contudo houve a possibilidade dela ter um olhar mais abrangente sobre a arte, visto que isso fez toda a diferença em sua vida profissional.

Natã Ferreira, do Grupo Cruor, por sua vez, diz que "pertencimento é um termo muito pesado para ser colocado dessa forma. Mas podese dizer que participar de tarefas/trabalhos/criação em conjunto, para mim, é sempre atualizar o significado de família". Entende-se que Natã não só se percebe como um ator no grupo, mas faz referência ao coletivo de teatro como uma família.

Franco Wilamy, do Grupo Arkhétypos, expõe que pertencer a um grupo:

Em termos práticos é ter vínculo como membro de algum projeto que se queira pensar teatro em grupo na universidade. Mas tive sorte de ter feito parte de reais comunidades, no sentido "comunitas" de partilhar a partir do encontro as potências criativas e de ser acolhido e se identificar com os outros ali. O grupo me segurou ali diversas vezes em que minha vida secular e as dificuldades de ser um aluno pobre com problemas sócio econômicos que me deixavam vulnerável. Acho que cada grupo constrói suas relações e eu fui um sortudo nas minhas, tenho grandes parcerias e afetos dos grupos aos quais fiz parte (Franco Wilamy, Grupo Arkhétypos).

É perceptível que Franco tem identidade com o grupo, falando 


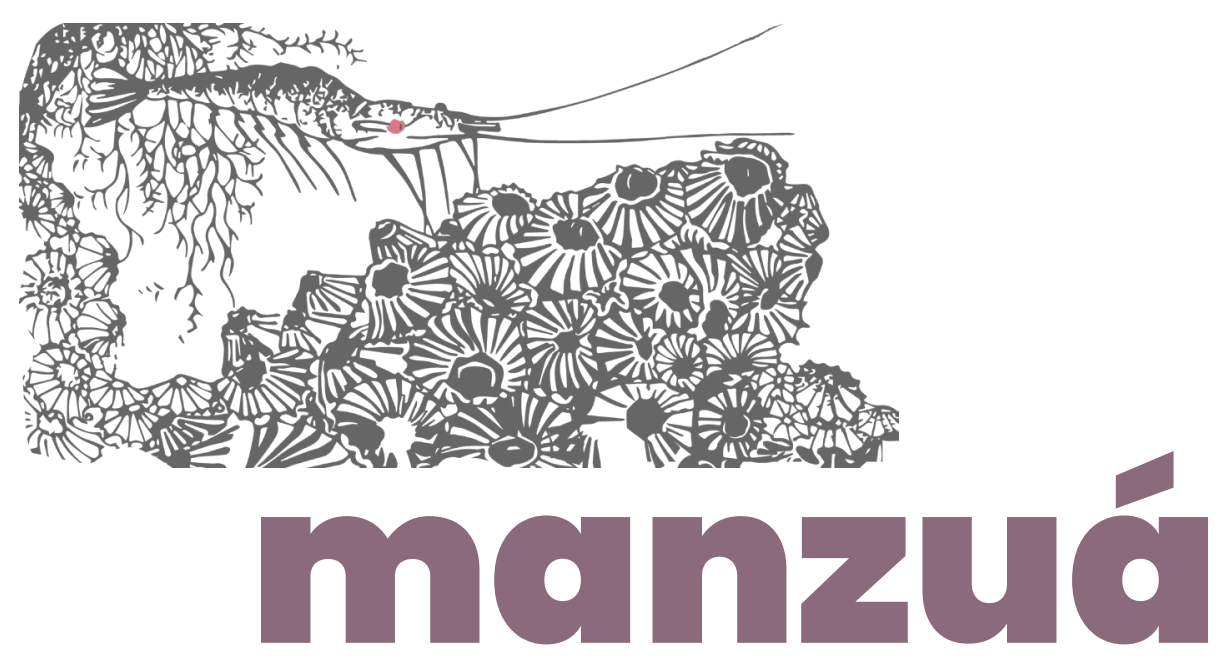

de suas relações, de se sentir comunidade, ter parceiros e sair da vulnerabilidade que vivia como pessoa de situação sócio econômica difícil e o Arkhétypos para ele abriu caminhos afetivamente falando.

Denilson David, do Grupo Eureka, reforça que pertencer a um grupo:

Foi a realização de um sonho. Através dessa participação eu pude entender melhor o que é ser/fazer teatro de grupo. Todos os benefícios, potencialidades e barreiras. E com certeza passe a valorizar ainda mais os grupos de teatro que eu já conhecia e aqueles que conseguem realizar seus trabalhos com maestria, harmonia, sensibilidade e sensatez através dos tempos (Denilson David, Grupo Eureka).

Ele tem uma visão de fazer teatro como um coletivo, e vê nisso um benefício ao seu crescimento profissional, num olhar o trabalho do outro com uma nova perspectiva, sendo sensivel à construção do conhecimento como prática.

Na fala de João Vitor, do Grupo Cruor, temos que, fazer teatro:

É como algo imprescindível. O cruor, por exemplo, tem uma temática específica, lida com os corpos diferenciados e esse lidar com esses corpos aciona a percepção da pluralidade, da diversidade a qual estamos inseridos, e que a nossa sociedade não respeita. No cruor havia pessoas com "padrões" gordo, magro, etc. E isso é um somar. Nara era uma provocadora no nosso trabalho, ela fazia-nos pensar nosso corpo, e tudo que fôssemos usar em cena. (João Vitor, Grupo Cruor).

Ressalta-se aqui a questão da diversidade e pluralidade nas reflexões do grupo Cruor, e ainda, a observância da necessidade do respeito às diferenças, pois o coletivo desenvolvido no grupo tinha 


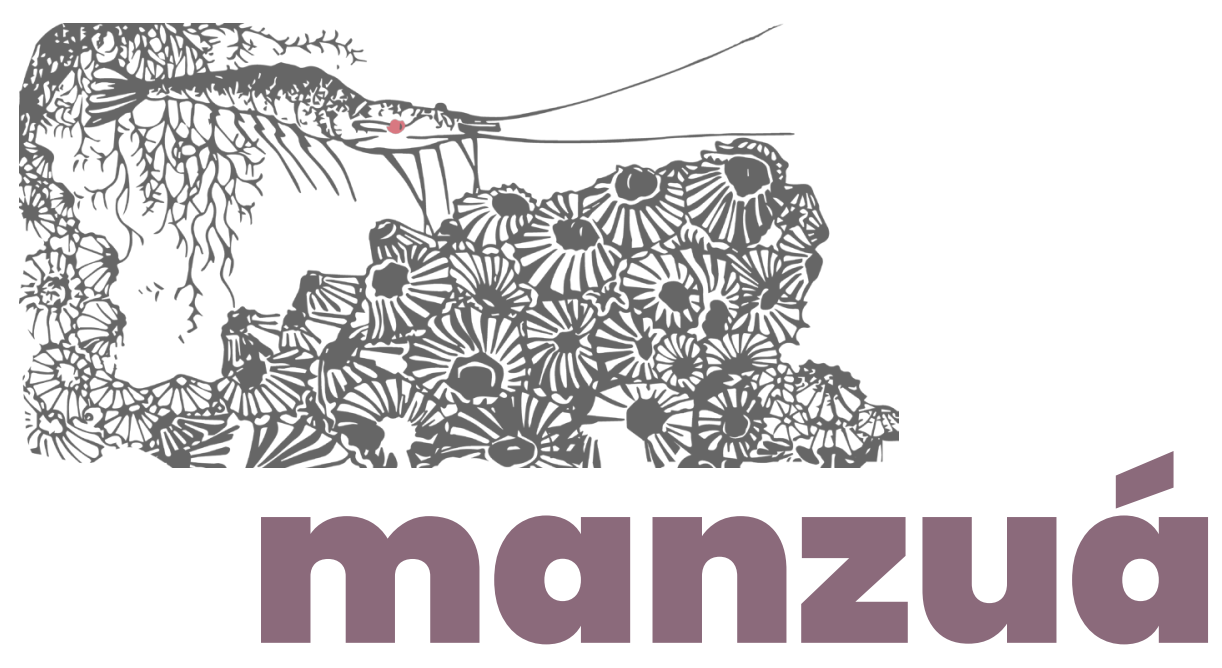

também um cunho provocativo, levando o público a uma reflexão, uma vez que corporalmente, ninguém é igual.

Ainda sob o olhar dos questionamentos feitos durante a pesquisa de campo, foi perguntado aos atores/estudantes o que é importante para eles em um grupo universitário de teatro. Com relação isso, Allan Phillype, do Grupo Arkhétypos, reforça que "o aprender em grupo... ter responsabilidade... compreender o que é ser família e, principalmente, aprender uns com os outros é uma troca interpessoal. Na verdade, todos aprendem coletivamente.

Na fala de Franco Wilamy, do esmo grupo, percebemos que, para ele o que importa em um grupo universitário é:

O canal aberto de acesso democrático as mais variadas possibilidades do fazer teatral, sem hierarquias. A potência do trabalho coletivo na soma das potências individuais. A formação artística continuada e sobretudo humana. Teatros universitários não devem seguir a lógica produtiva de mercado, mas sim dar ênfase ao suporte pedagógico e criativo se seus membros. (Franco Wilamy - Grupo Arkhetypos).

Na colocação de Franco, é de se perceber que para se fazer teatro na universidade é preciso um suporte pedagógico, e que haja uma interação do trabalho coletivo com o individual, considerando a variedade de conhecimentos entre seus pares para uma construção democrática do processo criativo. Denilson David, do grupo Eureka, aponta que:

O Grupo universitário é importante por vários aspectos, dentre eles: o trabalho em equipe, aprender a lidar com o diferente, aprender a ouvir, a respeitar e a colocar suas opiniões. Assim como é importante, a experimentação, os contatos, as parcerias e os laços que são criados (Denilson David, Grupo Eureka). 


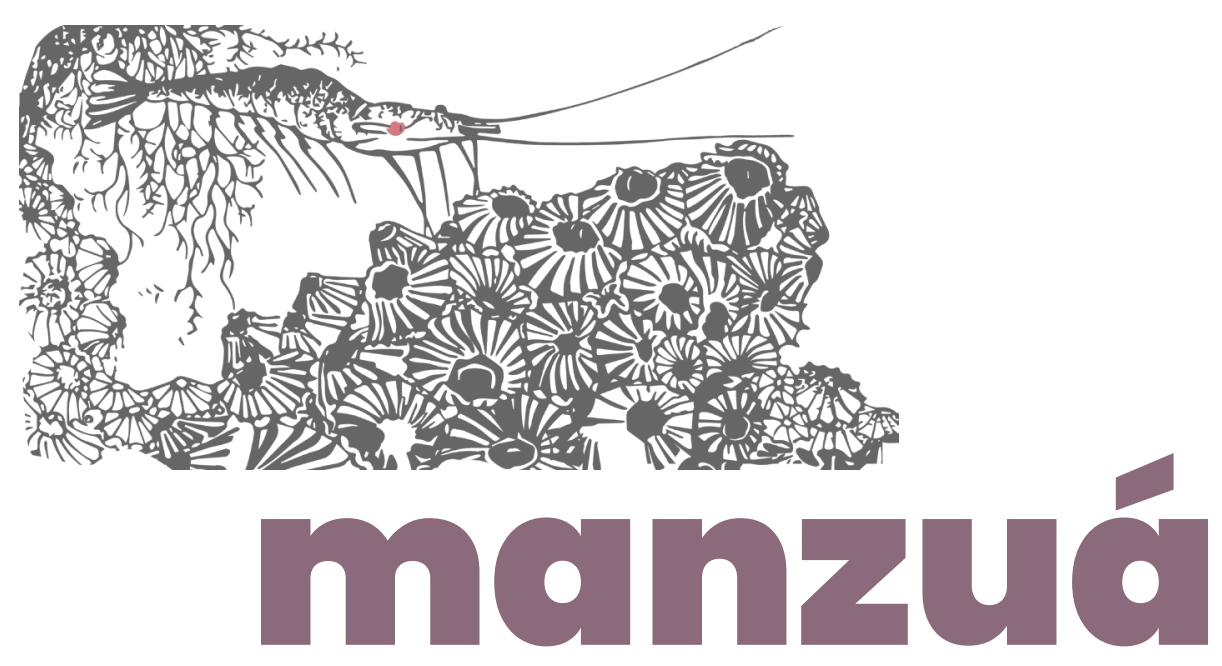

O ator em sua fala traz aspectos do desenvolvimento de habilidades com relação ao pertencimento a um grupo universitário, essas habilidades são desenvolvidas no saber ouvir, respeitar a opinião do outro e as diferenças, para assim criar parcerias e novos laços no fazer teatro.

Para Hélio Júnior, do Grupo GABOTUN:

O grupo é importante por vários motivos, como já comentei nas questões anteriores. Bom, vários grupos surgiram na universidade, como teatro oficina no Curso de Direito, vários grupos tiveram suas manifestações dentro da universidade, ou foram formados nela, enfim. Isso é importante. O grupo na universidade tem caráter experimental, estudando teatro, praticando-o. Agora quando o grupo torna-se profissional ele acaba seguindo um caminho fora da universidade, mas, claro, o grupo tem a possibilidade de crescer dentro da mesma através dos laboratórios, dos experimentos, onde estudantes pesquisam, leem, praticam e quando isso funciona esses grupos tendem a continuar fora da universidade (Hélio Junior, Cia GABOTUN).

Apreende-se na fala de Hélio Júnior, que é válido o caráter experimental de um grupo e ele também reforça a necessidade de se manter um laboratório para os experimentos na universidade, de forma que os grupos possam crescer dentro e fora desse contexto, unindo a pesquisa, a teoria e a prática num mesmo espaço educacional.

Celina, da Cia GABOTUN, salienta que:

É importante a multidisciplinaridade, O GABOTUN, tinha pessoas de vários cursos e com várias experiências de vida e isso era extremamente desafiador e instigante, nos proporcionava um aprendizado que só existia naquele ambiente. Foi muito, muito importante para minha vida 


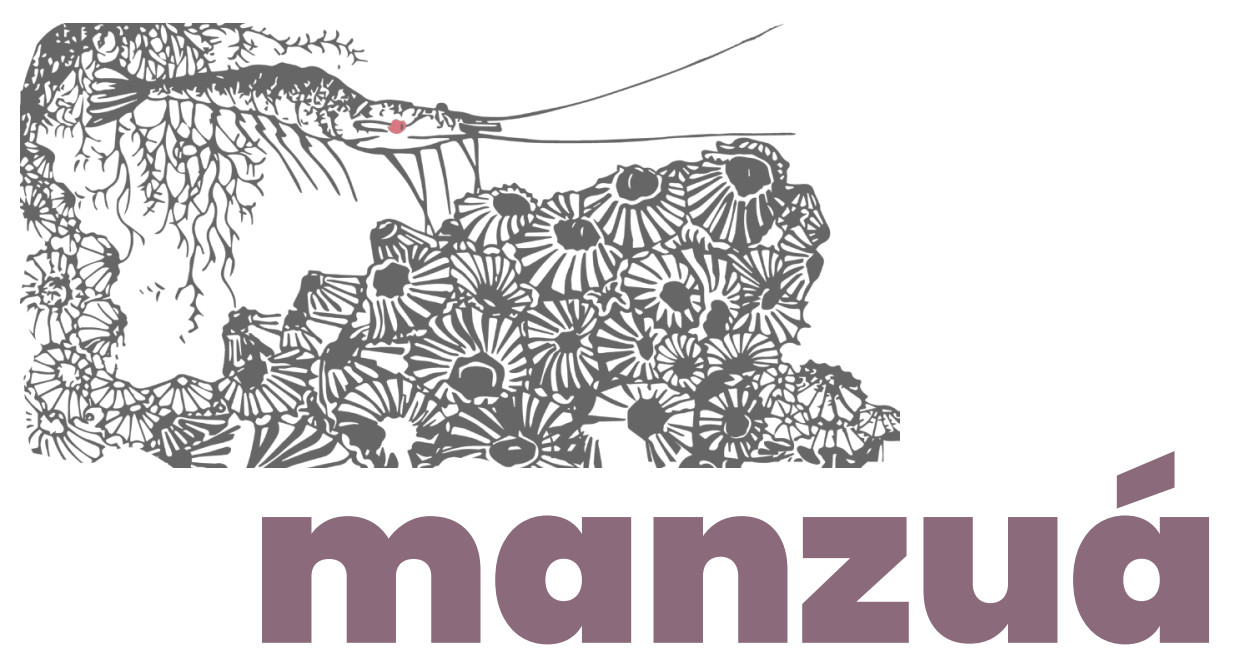

profissional, sou grata por tudo que vivi e aprendi com o grupo (Anna Celina, Cia GABOTUN).

Essa fala de Celina corrobora com as respostas de Natã, do Grupo Cruor, onde percebemos nesse contexto o adendo de ser também um processo de aprendizado na prática, ou seja, aprender fazendo, onde há a multiplicidade de saberes.

Trazendo, ainda, o relato de João Vitor, destaca-se que, para ele o que se faz importante num grupo universitário é:

saber respeitar as diferenças, saber lidar com elas, é olhar para o outro de modo afetuoso, é acolher o outro. Sobretudo quando o "outro" é novo. A gente precisa ter essa consciência de chegar em um espaço que eu não conheço, uma linguagem que eu não domino, uma experiência que eu não tenho. O grupo precisa se colocar enquanto grupo pra que venham a acolher aquele novo, e isso significa muito no cruor. (João Vitor, Grupo Cruor).

Aqui, é retomado o mesmo pensamento de Denilson David, do grupo Eureka, com relação à acolhida do outro nas suas habilidades e na consciência do novo que precisa aprender a ensinar ao outro que está chegando à equipe.

Refletindo sobre os relatos expostos pelos sujeitos da pesquisa, verifica-se a recorrência de termos como "teatro", "formação", "corpo", "academia", "metodologia", "criação" e Mariz (2008) vai dizer que "[...] Tudo que se realiza do ponto de vista do saber e da criação envolve necessariamente o corpo e o mundo no qual se vive".

Assim, é possível dizer que o corpo no teatro é ato que comunica, cria. O corpo é instrumento do fazer artístico em construção. O corpo é potência em ação. E, coadunando com Marcílio Vieira (2016, p. 62) "[...] o corpo não se reduz ao espaço, mas seu movimento é meio de percepção do espaço, do tempo e da ação". Isso remete ao corpo ser visto como um elemento carregado de história, que ao estar em 


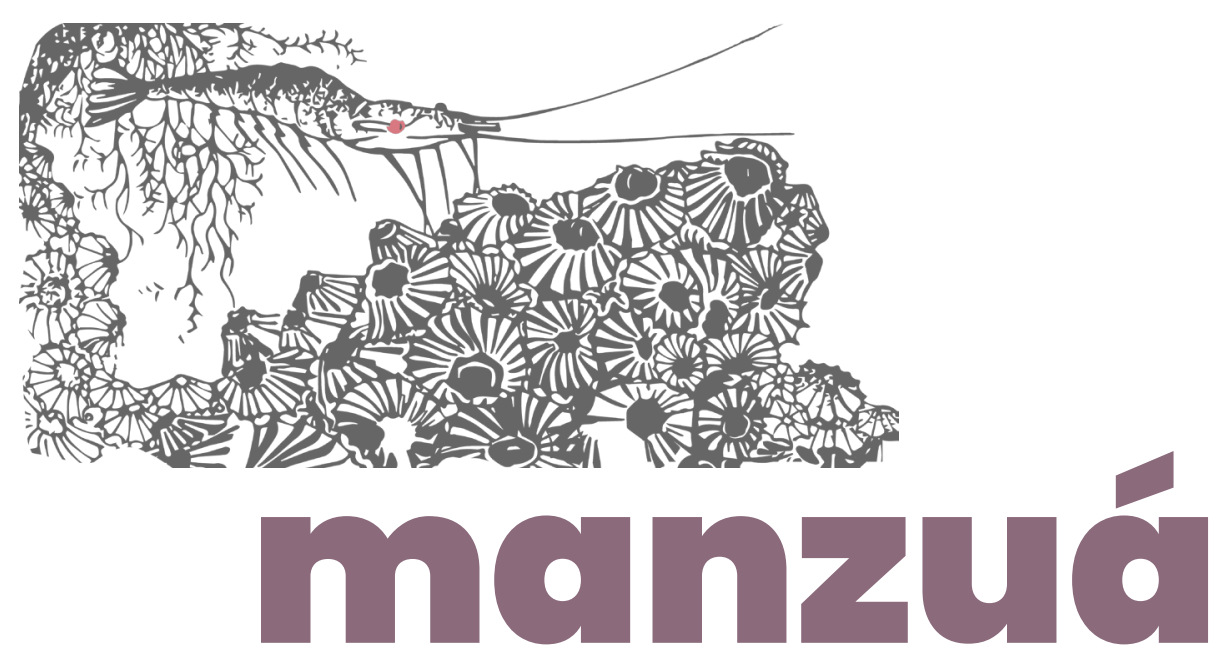

laboratório (trabalho prático, ensaio), começa-se a entrar nesses níveis de energia, das memórias afetivas resguardadas e postas para fora, com ações físicas. Logo, o corpo ultrapassa os níveis de suas próprias limitações.

Através de práticas diárias, é possivel perceber a evolução do corpo a que se constrói, sempre há um início para a prática teatral e é pertinente conhecer antes de tudo o corpo. Perceber é adentrar no íntimo mais profundo desse corpo-alma, que se configura na arte de criar, de evoluir, transcender.

Merleau-Ponty apud Mariz (2008) dirá que a arte não é feita com discurso interior ou imagens, mas com linguagem. Assim, o teatro também é uma arte da linguagem. Uma linguagem que demanda sinceridade, busca e o ato de fazer, não fica apenas no terreno das memórias, ou das ideias. Quando o corpo se conecta com nosso interior, é possível vê-lo se transformando e isso é linguagem artística em ação.

Schechner apud Mariz (2008) reforça que:

O teatro é terreno fértil para se inventar ou recriar possibilidades, para se brincar de ser outros. Nele, o próprio corpo é reinventado; tem suas capacidades ampliadas quase ao extremo. O teatro é um espaço que, por suas próprias características, possibilita a desconstrução e, ao mesmo tempo, o reencantamento do mundo. (SCHECHNER apud MARIZ, 2008, p. 156).

Ao refletir sobre o pensamento supracitado, é notável o lugar de diálogo, de encontro, de compartilhamentos que o teatro possibilita, o corpo torna-se a via de deslocamentos e trajetos que é explorado a cada processo de criação, a cada prática, daí é possível conectar a ideia de experiência à vida profissional como formação e construção do indivíduo no fazer teatral.

Assim, é possível associar o termo experiência empregada 


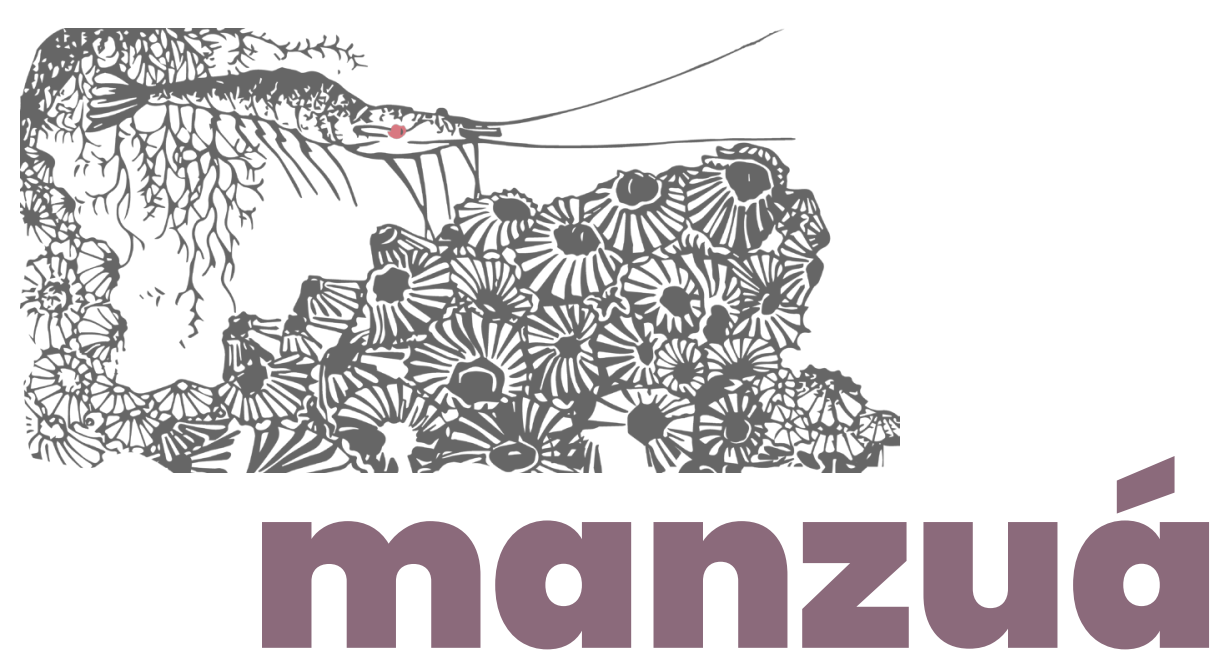

pelos entrevistados, no sentido atribuído por José Larrosa (2002), ao dizer que quando ela acontece produz significativas vivências e que precisa ser compartilhada entre os discentes e seus pares no cotidiano educativo.

Logo, a experiência dos sentidos das ações e dos fazeres cotidianos; a repetição e domínio da ação; as (im)possibilidades de comunicabilidade do vivido; os impactos, os afetos; as relações entre vivência e experiência tem a ver com a legitimidade do saber como experiência, ou seja, "[...] um saber particular, subjetivo, relativo, contingente, pessoal [...] que não pode separar-se do indivíduo concreto que o encarna" (LAROSSA, 2002, p. 27), mas que se agrega à criação.

A experiência tem papel formador e é parte constituidora do sujeito. Ela envolve fatores que, segundo Larrosa (2002), não pode ser reduzida ao simples "fazer". Experienciar, para ele, é viver determinadas condições que dão possibilidade para que a experiência se efetive.

A experiência não se basta como algo exterior ao sujeito, mas sinaliza uma interface entre interior e exterior; logo, o sujeito que a vive, no sentido arrogado por Larrosa (2002), permite que algo the aconteça, Ihe toque, Ihe suceda. O sujeito da experiência é consciente de sua condição de construtor do seu conhecimento, de sua personalidade e de sua formação. Ao sujeito que vive a experiência, algo Ihe acontece, ele não se informa simplesmente; ele passa a ser autor do processo em construção.

Para o autor supracitado,

A experiência, a possibilidade de que algo nos aconteça ou nos toque, requer um gesto de interrupção, um gesto que é quase impossivel nos tempos que correm: requer parar para pensar, parar para olhar, parar para escutar, pensar mais devagar, olhar mais devagar, e escutar mais devagar; parar para sentir, sentir mais devagar, demorar-se nos detalhes, suspender a opinião, suspender o juízo, suspender a vontade, suspender o automatismo da ação, cultivar a atenção e a 


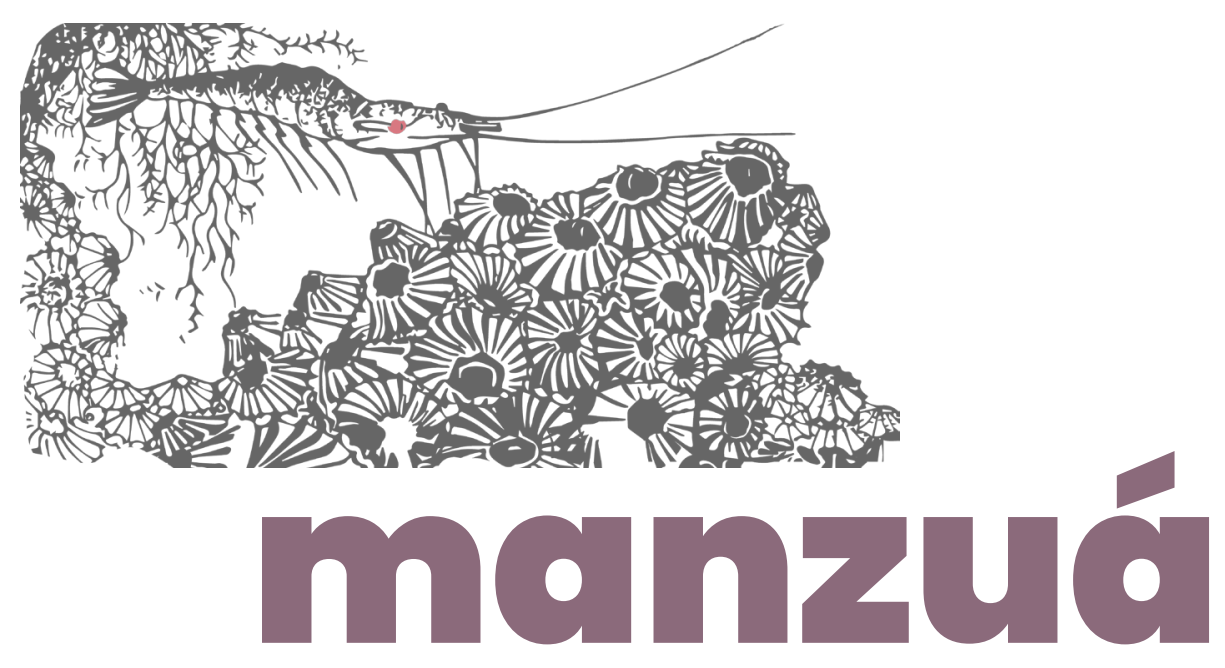

delicadeza, abrir os olhos e os ouvidos, falar sobre o que nos acontece, aprender a lentidão, escutar aos outros, cultivar a arte do encontro, calar muito, ter paciência e dar-se tempo e espaço. (LARROSA, 2002, p. 24).

Estes elementos, para o filósofo citado, são fundamentais para que o sujeito se torne capaz de experienciar. Notamos que isso não é simples e que o sujeito é o principal responsável por buscar criar condições de possibilidade para que algo lhe aconteça.

O sujeito da experiência em Larrosa (2002) é aquele que tem a capacidade de olhar para seu tempo com paciência, com lentidão, com demora nos detalhes, num gesto de interrupção. Logo o sujeito da experiência não é aquele que simplesmente executa a ação, que se informa e opina, que age por impulsos e desejos ou que participa de inúmeras atividades, mas é aquele que admite sua receptividade diante da experiência que vivencia.

Creio que as experiências vivenciadas pelos alunos nos projetos de extensão já comentados produziram neles novos olhares para o fazer teatral, principalmente quando vivenciaram e puderam dialogar com esses fazeres na sua experiência continuada dentro da universidade e fora dela.

Osgrupos de teatro se "encontram"nesseespaçocontemporâneo para as diferentes formas de criar, de treinar o ator, tendo e buscando a necessidade de se reinventarem na atualização de suas práticas criativas, bem como em compartilharem saberes coletivos, desenvolvendo meios "colaborativos" no fazer teatral.

Cabe salientar que todo esse processo de evolução em torno dos grupos leva-os a novos saberes e estratégias de crescimento, como a busca de profissionalização e, consequentemente, a novos modos de trabalho como o processo colaborativo.

Denomino o processo colaborativo como um modo de trabalho, por entender que não há uma rigidez metodológica 


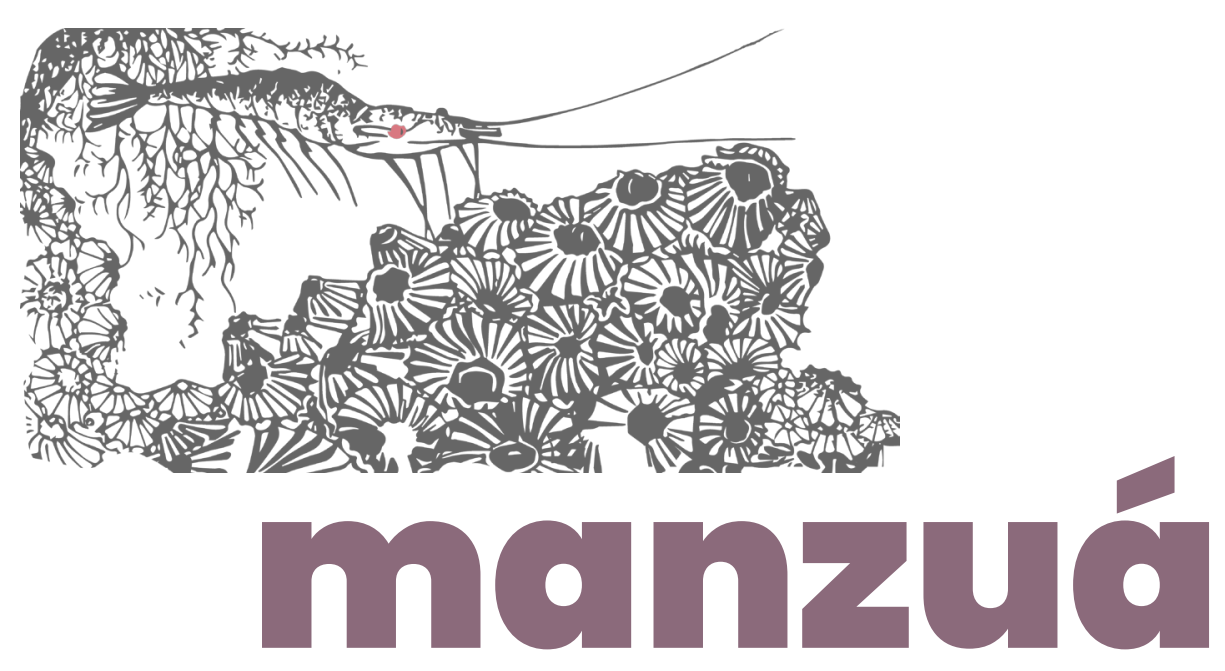

contida nas experiências que se realizam sob a égide da expressão. O que há é um escopo de valores que permeiam as práticas de diversos grupos, que daí conformam seus experimentos procedimentais (ARY,2015, p. 5).

O movimento dos grupos teatrais no Brasil, tem sido cada vez mais necessário e fundamental na cena contemporânea e isso ocorre pelo fato de uma grande quantidade de grupos de teatro estarem desenvolvendo e disseminando suas práticas coletivas teatrais por diversas regiões brasileiras, se mantendo resistentes em suas atividades criativas no âmbito cultural, como também vem ocorrendo na UFRN.

Os grupos teatrais ainda são vulneráveis, pois nem sempre os integrantes permanecem, ou conseguem apoio financeiro (patrocínios). E, como o apoio a cultura ainda é muito escassa, os editais para estes grupos também são insuficientes.

O apoio financeiro (como patrocínios e incentivos à cultura com premiações e editais) é importante também para os grupos se manterem fisicamente numa determinada estrutura. Os grupos da extensão universitária, por exemplo, (chamados também de projetos de extensão), recebem o apoio financeiro da universidade, mas concorrem a editais que ajudam na consolidação dos mesmos, além de levar a arte para diversos lugares.

Contudo, para continuarem seus trabalhos, os grupos da categoria, sem apoios financeiros, formam suas próprias estratégias, nas quais geram sua permanência, lembrando muito o teatro amador que se constituía independentemente. Mas, "essa independência não significa necessariamente assumir uma atitude de ruptura absoluta com procedimentos que caracterizam o mercado cultural, mas implica a busca de um espaço de autonomia" (CARREIRA, 2006, p. 9).

Nessa perspectiva, muitos grupos adentram em um processo de profissionalização, isto é, se aperfeiçoam em suas práticas artísticas, buscando reconhecimento mundo afora e trabalhando diferentes 


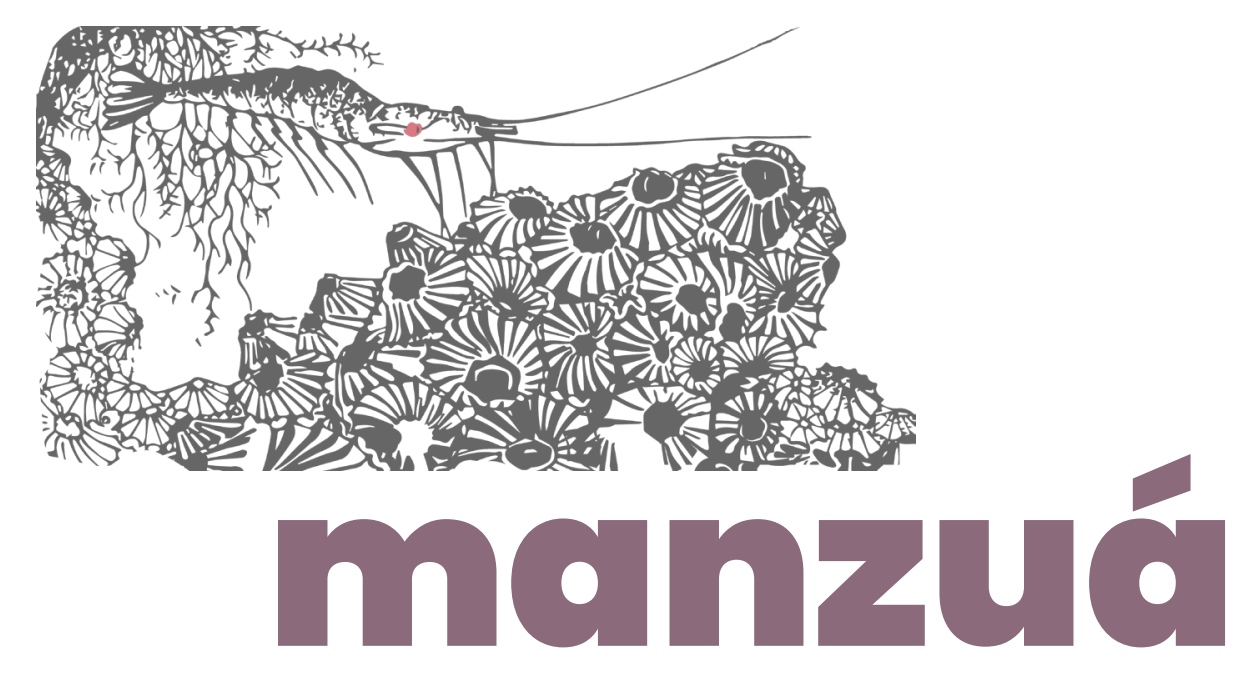

linguagens artísticas (envolvendo dança, teatro, performance). Isso, de certa forma, alimenta o grupo, dando a possibilidade de criar práticas artísticas que não fiquem somente em laboratórios de criação ou na universidade.

A universidade, por sua vez, é um espaço em que pode haver produção, reflexão e o compartilhar/trocas sobre diferentes estéticas teatrais no campo da arte, é o lugar gerador de conhecimento que deve ser lançado e compartilhado fora dela, propiciando, ainda, a formação de plateia e potencializando a formação acadêmica do discente, bem como o seu crescimento pessoal, sendo isso percebido através das entrevistas aplicadas com os questionários.

Através dos questionários pude perceber o quão é relevante e necessária a discussão e reflexão sobre as diferentes formas de um grupo teatral re(existir), especialmente dentro da universidade. Os grupos re(existem) através de suas práticas diárias de criação artística, muita disciplina, o processo metodológico (se identificando em uma ou mais estéticas teatrais) e o próprio processo de criação que é a "força motriz" na existência de um grupo.

Os grupos de extensão dentro do DEART-UFRN, por exemplo, contribuem para sua (re)existência. Isto é, são projetos os quais estão alicerçadas para a continuação dos processos criativos dos alunos, como também são fontes geradoras de conhecimento na área artística tanto para a comunidade interna da UFRN como para a comunidade externa, pois muitas pessoas são convidadas a participar de oficinas, palestras e muitas delas não são artistas/atores.

Além de se perceber a autonomia desses grupos, que defendem suas escolhas estéticas (trabalhando sob vieses políticos, sociais) e passam a inspirar outros grupos e artistas. Por isso, a universidade, inserida nesse lugar de trans(formação), muito auxilia nesse viés.

Esses Grupos uma vez concretizados, possibilitam produção artística, capacitação dos estudantes/artistas em diferentes estéticas teatrais e a continuação do projeto para outros novos participantes, pois o grupo gera fluxo, movimento de pessoas por si próprio. 


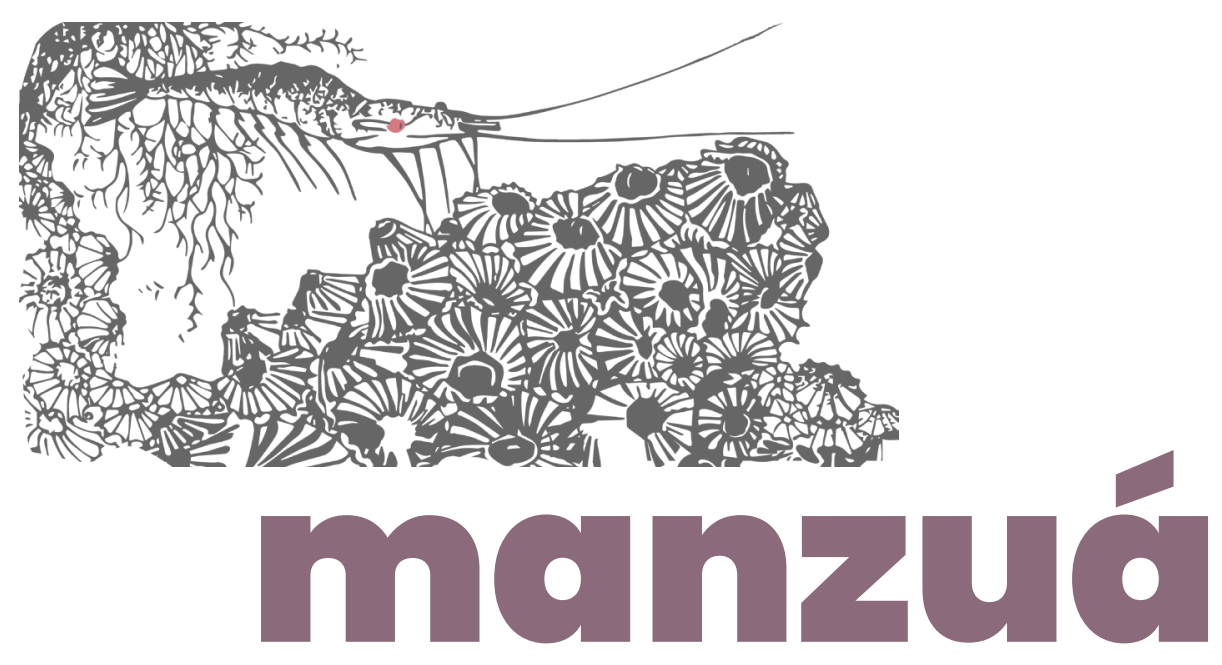

É importante, registrar aqui que essa pesquisa vai buscando 'atravessar' esses grupos que permearam o cenário artístico teatral da UFRN e que nos provoca enquanto grupos que buscam suas formas peculiares de fazer teatro, de fazer arte; grupos que resistiram e criaram sua própria organização.

Todos estes grupos, coletivos, ou projetos de extensão são de grande importância para a política de desenvolvimento da cultura local, bem como da UFRN, e para formação de plateia, levando para o público um teatro reflexivo, que prima pela criticidade eque é acessível com linguagens diferenciadas de se fazer teatro na universidade e muitos deles se constituindo em suas práticas/vivências a partir do processo colaborativo.

Todos os grupos teatrais, quer de caráter semiprofissional, quer de caráter artístico e de pesquisa são basilares para o entendimento do objetivo dessa pesquisa. A compreensão da criação desses grupos nos possibilita perceber, no âmbito universitário, em particular, aqueles que se organizam semiprofissionalmente, como são desenvolvidos e resistem na UFRN. 


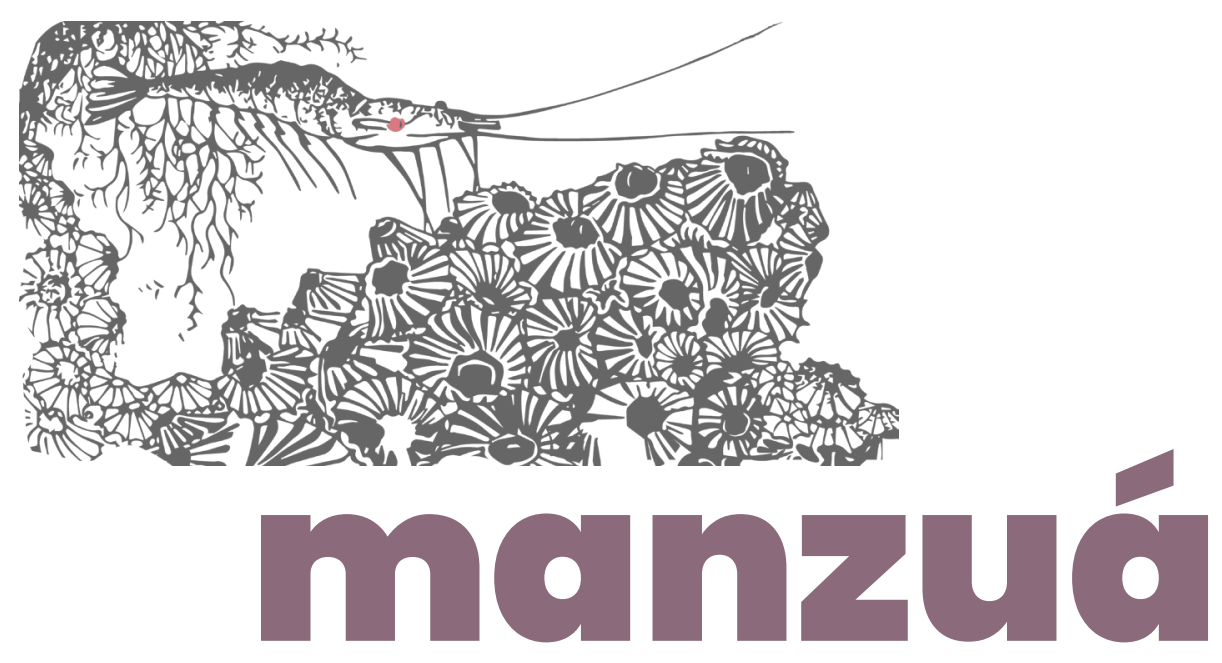

\section{Referencial}

ARY, R. Princípios para um processo colaborativo. Universidade Federal do Rio Grande do Sul. Revista CENA n 18, 2015.

BARDIN, L. Análise de conteúdo. Lisboa: Edições 70, 1977.

CARREIRA, A. L. A. N. Formação do ator e teatro de grupo: periferia e busca de identidade. In: MALUF, Sheila Diab; AQUINO, Ricardo Bigi (Org.). Dramaturgia em cena. Maceió; Salvador: Eufal; Edufba, 2006. p. 49-59. GERMAY, R. Do teatro universitário à associação internacional do teatro na universidade. Moringa, João Pessoa, v.l, n.1, p.65-77, jan. 2010. Universidade Federal da Paraíba.

LARROSA, J. Notas sobre a experiência e o saber de experiência. Revista Brasileira de Educação. ANPED, n.19, jan-abr 2002.

MARCONI, Marina de Andrade; LAKATOS, Eva Maria. Fundamentos de Metodologia Científica. 2003, p. 165. Ed. Atlas. São Paulo, SP. Edição: 5a . Ano: 2003.

MARIZ, Adriana Dantas de. A Ostra e a Pérola: Uma visão antropológica do corpo no teatro de pesquisa. São Paulo: Perspectiva, 2008.

SILVA, S. S. Saudades Z(é): metaforizando a construção do corpo brincante. 2017. 100 f. Dissertação de Mestrado. Universidade Federal do rio Grande do Norte.

UFRN/CONSEPE. Resolução nº 077, de 27 de junho de 2017. Natal: UFRN, 2017.

VIEIRA, M. S. Persona de dança: Edson Claro. Curitiba: Editora Prismas, 2016. 